\title{
Effect of Glyphosate and Zinc Application on Yield, Soil Fertility, Yield Components, and Nutritional Status of Soybean
}

\author{
A. Moreira, L. A. C. Moraes, T. Furlan \& R. Heinrichs
}

To cite this article: A. Moreira, L. A. C. Moraes, T. Furlan \& R. Heinrichs (2016) Effect of Glyphosate and Zinc Application on Yield, Soil Fertility, Yield Components, and Nutritional Status of Soybean, Communications in Soil Science and Plant Analysis, 47:8, 1033-1047, DOI: 10.1080/00103624.2016.1165829

To link to this article: https://doi.org/10.1080/00103624.2016.1165829

Accepted author version posted online: 31

Mar 2016.

Published online: 18 May 2016.

Submit your article to this journal $2 \pi$

Џ Article views: 112

Q View related articles $\sqsubset$

View Crossmark data $\asymp$

4 Citing articles: 2 View citing articles 지 


\title{
Effect of Glyphosate and Zinc Application on Yield, Soil Fertility, Yield Components, and Nutritional Status of Soybean
}

\author{
A. Moreiraa, L. A. C. Moraes ${ }^{a}$, T. Furlan ${ }^{b}$, and R. Heinrichs ${ }^{c}$ \\ aDepartment of Soil Science and Plant Nutrition, National Soybean Research Center, Londrina, Paraná, Brazil; \\ bepartment of Agronomy, Londrina State University, Londrina, Paraná, Brazil; 'Department of Animal Science, São \\ Paulo State University, UNESP/Dracena, Dracena, São Paulo, Brazil
}

\begin{abstract}
Glyphosate is a widely used nonselective herbicide for the control of agricultural weeds. It is being increasingly used in glyphosate resistant genetically modified plants. However, there are few studies on its effects on the nutritional status of soybean, particularly on the uptake of zinc ( $\mathrm{Zn})$. Two experiments were conducted under field conditions in a Typic Quartzipsamment and an Orthic Ferralsol to investigate the effect of glyphosate application $\times \mathrm{Zn}$ interaction on soil fertility, yield components, seed yield (SY), shoot dry weight (SDW) yield, and nutritional status of soybean. The five $Z n$ rates $0,3,6,9$, and $12 \mathrm{~kg} \mathrm{ha}^{-1}$ were used in two soybean varieties [BRS 133 (conventional-NGM) and its essentially derived transgenic line BRS 245RR (GM), which was divided into: with (+Gly) and without (-Gly) glyphosate application. Only the $P$ (phosphorus) and $\mathrm{Zn}$ available concentrations in the soil were impacted by $\mathrm{Zn}$ rates. However, the available $\mathrm{P}$ concentration only decreased in the soil planted with GM soybean. Mehlich 1 and diethylenetriaminepenta acetic acid-triethanolamine (DTPATEA), 7.3 extractants were effective to determine the available $\mathrm{Zn}$. In the two crop sites, the number of pods per plant (NPP) and the SDW yield were affected by the interaction varieties $\times \mathrm{Zn}$. SY was influenced by the application of the herbicide, reducing a potential phytotoxic effect with the use of high rates. Regarding the nutrients, only the foliar calcium (Ca), boron (B), iron (Fe), and manganese ( $\mathrm{Mn}$ ) concentrations were negatively affected by glyphosate, and in the case of $\mathrm{Zn}$, the difference occurred only between the varieties BRS 133 and BRS 245RR.
\end{abstract}

\section{ARTICLE HISTORY}

Received 28 April 2015

Accepted 27 December 2015

\section{KEYWORDS}

Acid soils; effect of the herbicide; Glycine max; uptake of nutrients; $\mathrm{Zn}$ extractants

\section{Introduction}

The glyphosate [(N-phosphonomethyl-glycine)] use resistant genetically modified soybean [Glycine $\max$ (L.) Merril] by $85 \%$ of Brazilian farmers (Ikeda 2013) resulted in a considerable increase in the use of this herbicide alone or combined with other products, particularly in post-emergence control of weeds, with three to four applications during the crop cycle.

Glyphosate is the world's most widely used systemic nonselective herbicide, recommended for the control of both annual and perennial weeds (Ikeda 2013; Rodrigues and Almeida 1998). Its mechanism of action is based on the inactivation of 5-enolpyruvylshikimate-3-phosphate (EPSP) synthase (Coupland 1985), which prevents the synthesis of aromatic amino acids (AAs) (tryptophan, tyrosine, phenylalanine, and histidine) (Delannay et al. 1995; Graham and Webb 1991) and adverse effects on photosynthetic carbon (C) metabolism, and translocation of sucrose in the plants (Cakmak et al. 2009).

CONTACT A. Moreira adonismoreira66@gmail.com N National Soybean Research Center, Rodovia Carlos João Strass, acesso Orlando Amaral, s/n, Caixa Postal 231, Distrito de Warta, 86001-970, Londrina, Paraná, Brazil.

Color versions of one or more of the figures in the article can be found online at www.tandfonline.com/lcss. 
Glyphosate resistant soybean was developed with the insertion of strain cp4 from Agrobacterium $\mathrm{sp}$, which encodes a variety resistant to excitatory postsynaptic potential (EPSPS). Notwithstanding, according to some reports, the use of the herbicide may interfere with nutrient absorption (Cakmak et al. 2009; Zobiole et al. 2012). Zinc participates in the synthesis of aromatic AAs such as tryptophan, which is a precursor of indole-3-acetic acid (IAA), a plant hormone required for cell growth, maintenance of apical dominance, among other physiological processes (Davies 1995; Marschner 1995).

Zinc and boron (B) are the most commonly deficient micronutrients in the tropics (Fageria 2009). In the plant, $\mathrm{Zn}$ is generally uptake as a divalent cation zinc $\left(\mathrm{Zn}^{2+}\right)$ (Havlin et al. 1999), and acts as a constituent or activator of several enzymes, being directly involved in the metabolism of nitrogen $(\mathrm{N})$, photosynthesis, respiration, synthesis of AAs and proteins, and hormone control. The lack of $\mathrm{Zn}$ causes a decrease of flowering and fruiting, reduced elongation of the cells, resulting in shorter internodes and poor root system development (Fageria 2009; Loué 1993; Marschner 1995). In the soil, different extractants were evaluated (Moreira, Moraes, and Fageria 2015; Oliveira et al. 2003), as well as the $\mathrm{Zn}$ concentrations in soybean leaves to determine the most appropriated soil extractants for available $\mathrm{Zn}$ in this crop production system.

The present study aimed to assess the effects of glyphosate application and $\mathrm{Zn}$ interaction, soil fertility, yield components, seed yield (SY), shoot dry weight (SDW), and nutritional status of two soybean varieties: one conventional (NGM) and its glyphosate resistant essentially derived transgenic line (GM) grown under two types of soil (Typic Quartzipsamment and Orthic Ferralsol) and climate conditions. In both soils was also evaluated the $\mathrm{Zn}$ available with Mehlich 1 and DTPA-TEA, pH 7.3 extractants.

\section{Material and methods}

\section{Field experiments}

Experiments were done at two Brazilian sites: Ponta Grossa, Paraná State $\left(25^{\circ} 05^{\prime} 42^{\prime \prime} \mathrm{S}\right.$ and $50^{\circ} 10^{\prime} 43^{\prime \prime} \mathrm{W}$ ) on an Orthic Ferralsol ( $\mathrm{pH}$ calcium chloride $\left(\mathrm{CaCl}_{2}\right)=3.8, \mathrm{C}=10.9 \mathrm{~g} \mathrm{~kg}^{-1}$, $\mathrm{P}=1.2 \mathrm{~g} \mathrm{~kg}^{-1}$, potassium $\left(\mathrm{K}^{+}\right)=0.04 \mathrm{cmol}_{\mathrm{c}} \mathrm{kg}^{-1}, \mathrm{Ca}^{2+}=0.2 \mathrm{cmol}_{\mathrm{c}} \mathrm{kg}^{-1}$, magnesium $\left(\mathrm{Mg}^{2+}\right)$ $=0.2 \mathrm{cmol}_{\mathrm{c}} \mathrm{kg}^{-1}$, aluminum $\left(\mathrm{Al}^{3+}\right)=14 \mathrm{cmol}_{\mathrm{c}} \mathrm{kg}^{-1}$, potential acidity $\left(\mathrm{H}^{+}+\mathrm{Al}^{3+}\right)=7.4 \mathrm{cmol}_{\mathrm{c}} \mathrm{kg}^{-1}$, cation exchange capacity $(\mathrm{CEC})=7.8 \mathrm{cmol}_{\mathrm{c}} \mathrm{kg}^{-1}$, base saturation $(\mathrm{V})=5.6 \%, \mathrm{~B}=0.4 \mathrm{mg} \mathrm{kg}{ }^{-1}$, copper $(\mathrm{Cu})=1.7 \mathrm{mg} \mathrm{kg}{ }^{-1}$, iron $(\mathrm{Fe})=35.4 \mathrm{mg} \mathrm{kg}^{-1}$, manganese $(\mathrm{Mn})=8.9, \mathrm{mg} \mathrm{kg}^{-1}$, $\mathrm{Zn}=0.8 \mathrm{mg} \mathrm{kg}^{-1}$, clay $=350 \mathrm{~g} \mathrm{~kg}^{-1}$, and sand $=573 \mathrm{~g} \mathrm{~kg}^{-1}$ ), and Três Lagoas, Mato Grosso do Sul State $\left(20^{\circ} 45^{\prime} 04^{\prime \prime} \mathrm{S}\right.$ and $\left.51^{\circ} 40^{\prime} 42^{\prime \prime} \mathrm{W}\right)$ on a Typic Quartzipsamment ( $\mathrm{pH} \mathrm{CaCl}_{2}=4.4$, $\mathrm{C}=10.9 \mathrm{~g} \mathrm{~kg}^{-1}, \mathrm{P}=3.0 \mathrm{~g} \mathrm{~kg}^{-1}, \mathrm{~K}^{+}=0.11 \mathrm{cmol}_{\mathrm{c}} \mathrm{kg}^{-1}, \mathrm{Ca}^{2+}=1.0 \mathrm{cmol}_{\mathrm{c}} \mathrm{kg}^{-1}, \mathrm{Mg}^{2+}=0.3 \mathrm{cmol}_{\mathrm{c}}$ $\mathrm{kg}^{-1}, \mathrm{Al}^{3+}=0.3 \mathrm{cmol}_{\mathrm{c}} \mathrm{kg}^{-1}, \mathrm{H}^{+}+\mathrm{Al}^{3+}=3.1 \mathrm{cmol}_{\mathrm{c}} \mathrm{kg}^{-1}, \mathrm{CEC}=4.5 \mathrm{cmol}_{\mathrm{c}} \mathrm{kg}^{-1}, \mathrm{~V}=31.0 \%$, $\mathrm{B}=0.2 \mathrm{mg} \mathrm{kg}{ }^{-1}$, cooper $(\mathrm{Cu})=0.5 \mathrm{mg} \mathrm{kg}{ }^{-1}, \mathrm{Fe}=73.0 \mathrm{mg} \mathrm{kg}{ }^{-1}, \mathrm{Mn}=18.4, \mathrm{mg} \mathrm{kg}^{-1}$, $\mathrm{Zn}=0.5 \mathrm{mg} \mathrm{kg}^{-1}$, clay $=141 \mathrm{~g} \mathrm{~kg}^{-1}$, and sand $\left.=723 \mathrm{~g} \mathrm{~kg}^{-1}\right)$, in $4 \mathrm{~m} \times 8 \mathrm{~m}$ plots in randomized block design in $3 \times 5$ factorial arrangement, with four replicates. The treatments consisted of five $\mathrm{Zn}$ rates $\left(0,3,6,9\right.$, and $12 \mathrm{~kg} \mathrm{ha}^{-1}$-source: zinc sulfate heptahydrate $\left.\left(\mathrm{ZnSO}_{4} \times 7 \mathrm{H}_{2} \mathrm{O}\right)\right)$ and two parental varieties (BRS 133 and its essentially derived transgenic line BRS 245RR), and the latter was divided into two other varieties, resulting in three treatments: BRS 133, BRS 245RR with glyphosate (+Gly) and BRS 245RR without glyphosate (-Gly) application.

\section{Fertilization and Soybean planting}

In the total area, dolomite limestone (magnesium oxide $(\mathrm{MgO})>13 \%$ ) was applied to the soil at 0-20 cm depth to raise base saturation to 60\%. Except for $\mathrm{N}$ and $\mathrm{Zn}$, the fertilizations were performed according to TPS (2013). The micronutrients ( $\mathrm{B}, \mathrm{Cu}, \mathrm{Fe}$, and $\mathrm{Mn}$ ) and $\mathrm{Zn}$ rates corresponding to the treatments were mixed with gypsum calcium sulfate dihydrate 
$\left(\mathrm{CaSO}_{4} \times 2 \mathrm{H}_{2} \mathrm{O}\right)$ and incorporated with the use of a revolving hoe. The seeds were inoculated with Bradyrhizobium elkanii-SEMIA 587 and SEMIA $5019\left(4.0 \times 10^{9}\right.$ viable cells $\left.\mathrm{g}^{-1}\right)$ and treated with a solution containing molybdenum (Mo), cobalt (Co), and nickel (Ni) (TPS 2013).

\section{Crop management and Chlorophyll concentration}

At the V4 growth stage (Fehr et al. 1971), half of the plants with treatment BRS 245RR received glyphosate application (Roundup Ready ${ }^{\circ}$ ) at the rate of $1.5 \mathrm{~L} / \mathrm{ha}$ /application $\left(540 \mathrm{~g}\right.$ a.i. ha ${ }^{-1}$ ), by spraying at constant pressure of $276 \mathrm{kPa}$, maintained by compressed $\mathrm{CO}_{2}$. Following the glyphosate application, the plants were photographed for monitoring of visual symptoms of deficiency or phytotoxicity. At the R2 growth stage, the SPAD unit was measured from the third and fourth fully expanded trifoliate leaves from the apex of 20 plants per plot, and the values were later converted into chlorophyll concentration units $\left(\mathrm{mg} \mathrm{cm} \mathrm{cm}^{-2}\right)$ through equation $\hat{y}=16.033$ $+(7.5774 \times$ SPAD) (Fritschi and Ray 2007).

\section{Analysis of soil chemical properties}

Soil samples were collected at $0-20 \mathrm{~cm}$ depth for each treatment and they were air-dried and passed through a $2.0 \mathrm{~mm}$ sieve for quantification of $\mathrm{pH}$ in $\mathrm{CaCl}_{2} 0.01 \mathrm{~mol} \mathrm{~L}^{-1}$ using a 1:2.5 ratio, soil organic matter $(\mathrm{SOM})($ Walkley-Black $-C \times 1.724)$, available $\mathrm{P}$ and exchangeable $\mathrm{K}^{+}$(extracted by Mehlich 1) $\left(0.025 \mathrm{~mol} \mathrm{~L}^{-1}\right.$ of $\mathrm{H}_{2} \mathrm{SO}_{4}+0.05 \mathrm{~mol} \mathrm{~L}{ }^{-1}$ of $\left.\mathrm{HCl}\right)$. Exchangeable $\mathrm{Ca}^{2+}$ and $\mathrm{Mg}^{2+}$ extracted by potassium chloride $(\mathrm{KCl}) 1.0 \mathrm{~mol} \mathrm{~L}{ }^{-1}$, potential acidity $\left(\mathrm{H}^{+}+\mathrm{Al}^{3+}\right)$ estimated by SMP (Shoemaker, MacLean and Pratt) buffer, $\mathrm{B}$ extracted by hot water, $\mathrm{Cu}, \mathrm{Fe}$, and $\mathrm{Mn}$ available were extracted using the Mehlich 1 method and available Zn by Mehlich 1 (Mehlich 1978) and diethylene tetramine pentaacetic acid (DTPA)-triethanolamine (TEA)- $\mathrm{pH} 7.3$, (Lindsay and Norvell 1978). CEC was calculated by summing the exchangeable $\sum \mathrm{Ca}^{2+}, \mathrm{Mg}^{2+}, \mathrm{K}^{+}$, and $\mathrm{H}^{+}+\mathrm{Al}^{3+}$, according to methodologies described by Embrapa (1997).

\section{Collection of plant materials and foliar analysis}

In the R2 growth stage (Fehr et al. 1971), random samplings of the third and fourth fully expanded trifoliate leaves from the apex were performed in each treatment for foliar diagnosis. In the R7 growth stage, five plants were collected per plot ( $\sum$ stems, leaves, and pods) to quantify the SDW yield. These plant parts were then dried in forced ventilation oven at $65^{\circ} \pm 3 \mathrm{C}$ until reaching constant weight. After drying, the samples were weighed for determination of SDW yield. Only the 3rd and 4th trifoliate leaves were ground and subjected to chemical analyzes (Malavolta, Vitti, and Oliveira 1997). Total $\mathrm{N}$ was extracted by sulfuric $\left(\mathrm{H}_{2} \mathrm{SO}_{4}\right)$ digestion and determined by the micro-Kjeldahl method; $\mathrm{P}, \mathrm{K}, \mathrm{Ca}, \mathrm{Mg}, \mathrm{S}, \mathrm{Cu}, \mathrm{Fe}, \mathrm{Mn}$, and $\mathrm{Zn}$ were extracted by nitric $\left(\mathrm{HNO}_{3}\right)$-perchloric $\left(\mathrm{HClO}_{4}\right)$ acid digestion (2:1, v:v), with $\mathrm{P}$ and sulfur (S) determined by the spectrophotometric method using the blue molybdenum procedure and turbidimetry, respectively. Foliar B was obtained by incineration at $500^{\circ} \mathrm{C}$ and determined using the colorimetric reagent Azomethine- $\mathrm{H}$. The other nutrients were determined by atomic absorption spectrophotometry (Malavolta, Vitti, and Oliveira 1997).

Before harvest, 10 plants were randomly collected from each treatment to quantify the number of seeds per plant and per pod. Seed yield (SY) was determined after mechanized harvesting of the plots at the end of the cycle (R8 growth stage). SY data was converted into $\mathrm{kg} / \mathrm{ha}$ and corrected to $13 \%$ moisture, and the 100-seed weight was later quantified.

\section{Statistical analyzes}

According to the proposed design, the normality test was conducted for the assessed variables, which were subsequently subjected to analysis of variance (ANOVA-F test), mean comparison by Scott- 
Knott at the 5\% probability. Regression and correlation analyzes $(P \leq 0.05)$ were used to investigate the relationship between $\mathrm{Zn}$ rates and glyphosate application and the nutrients uptake, with, yield components, soil fertility, and physiological data and SY and SDW yield of the different parts of the plant and total. Correlations were established between $\mathrm{Zn}$ foliar concentration in each treatment, SDW yield and SY with the available Zn concentrations extracted with DTPA-TEA, 7.3, and Mehlich 1 extractants.

\section{Results and discussion}

\section{Soil chemical properties and evaluation of extractants}

The varieties NGM (BRS 133) and GM (BRS 245RR) without (-Gly) and with (+Gly) glyphosate application showed no varieties $\times \mathrm{Zn}$ rates on the nutrients concentrations in the soil. Regarding $\mathrm{Zn}$ rates (Tables 1 and 2 and Figures 1 and 2), only $\mathrm{P}$ and $\mathrm{Zn}$ concentration were significantly affected. The $\mathrm{P}$ available in the treatment -Gly in the GM variety grown in a Typic Quartzipsamment soil and in the NGM and GM (-Gly) grown in Orthic Ferralsol were affected by $\mathrm{Zn}$ rates $\left(\hat{y}=15.352+0.441 x, R^{2}=0.94, \hat{y}=1.666+0.357 x, R^{2}=0.80\right.$, and $\hat{y}=2.008+0.269 x, R^{2}=0.76$, $P \leq 0.05)$. Such results demonstrate the effects of the negative $\mathrm{Zn} \times \mathrm{P}$ interaction described by LopezGorostiaga and Malavolta (1974), Loneragan et al. (1982), Loué (1993), and Moreira and Malavolta (2001). However, the glyphosate use minimized this effect regardless of the type of soil. The absence of a significant effect of $\mathrm{Zn}$ rates on the other soil chemical properties was also reported by Ritchey et al. (1986) in corn (Zea mays), soybean and sorghum (Sorghum bicolor) crops grown in soil with low nutrients availability. The $\mathrm{pH}$ value and $\mathrm{P}, \mathrm{K}^{+}, \mathrm{Ca}^{2+}, \mathrm{Mg}^{2+}, \mathrm{S}-\mathrm{SO}_{4}{ }^{2-}, \mathrm{B}, \mathrm{Cu}, \mathrm{Fe}, \mathrm{Mn}$, and $\mathrm{Zn}$ concentration in a Typic Quartzipsamment were within or close to the levels indicated as suitable for the crops, while in an Orthic Ferralsol, only P concentration were below the minimum suitable concentration for soybean cultivation under the climate and soil conditions of the tropics (TPS 2013).

Mehlich 1 (M1) and DTPA-TEA, 7.3 extractants had high correlation coefficient in the available $\mathrm{Zn}$ determination, regardless of the type of soil and glyphosate application (Figure 2). Similarly to Fageria and Santos (2011), M1 extractant showed, in average, a higher rate of recovery of Zn than DTPA-TEA (higher than 63.9\%). This result also corroborates Abreu and van Raij (1996) and Moreira, Moraes, and Fageria (2015), who compared both extractants and found that the higher extraction capacity of M1 solution was due to the high acidity of the medium $\left(0.0625 \mathrm{~mol} \mathrm{H}^{+} \mathrm{L}^{-1}\right)$, that made occluded forms of $\mathrm{Zn}$ in soil that were unavailable for plant uptake more soluble and mobile, while the DTPA-TEA solution did not become more soluble because of its alkaline reaction $(\mathrm{pH}=7.3)$.

The correlations between foliar $\mathrm{Zn}$ concentration and the available concentration in the soil with M1 and DTPA-TEA, 7.3 extractants were similar to those observed by Abreu and van Raij (1996), Oliveira et al. (2003) and Moreira, Moraes, and Fageria (2015), with a significant correlation $(P \leq 0.05)$. This was also reported for $\mathrm{Zn}$ foliar concentration. However, DTPA-TEA solution showed higher correlation coefficients $(r=0.78,0.81$, and $0.78, P \leq 0.05)$, in the two types of soil and different varieties and managements adopted (Figures 1 and 2).

The two extractants obtained similar linear relations, with positive significance with the rates applied. The following equations were obtained for varieties BRS 133, BRS 245RR (-Gly), BRS 245RR (+Gly), and the average of the three types of management in the two sites. $x=\mathrm{Zn}$ rate in $\mathrm{kg} / \mathrm{ha}$ and $\hat{y}=$ soil concentration in $\mathrm{mg} \mathrm{kg}^{-1}$ :

a) Três Lagoas, Mato Grosso do Sul State (Typic Quartzipsamment)

Mehlich 1 extractant

BRS $133-\hat{y}=0.529+0.201^{\star} x, R^{2}=0.40, P \leq 0.05$;

BRS 245RR (-Gly) $-\hat{y}=0.389+0.195^{\star} x, R^{2}=0.48, P \leq 0.05$; 
Table 1. Chemical properties of a Typic Quartzipsamment as influenced by zinc rates within the NGM-BRS 133 and GM-BRS $245 R$ [without (Gly) and with (+Gly) glyphosate application] soybean cultivars in Mato Grosso do Sul State, Brazil.

\begin{tabular}{|c|c|c|c|c|c|c|c|}
\hline \multirow[b]{2}{*}{ Soil properties } & \multicolumn{6}{|c|}{ Zinc, $\mathrm{kg} \mathrm{ha}^{-1}$} & \multirow[b]{2}{*}{ F-test } \\
\hline & 0 & 3 & 6 & 9 & 12 & Average & \\
\hline \multicolumn{8}{|c|}{ BRS 133} \\
\hline $\mathrm{pH}, \mathrm{CaCl}_{2}$ & 5.72 & 5.83 & 5.72 & 5.94 & 5.90 & 5.82 & NS \\
\hline$C, \mathrm{~g} \mathrm{~kg}^{-1}$ & 7.81 & 7.71 & 7.66 & 7.65 & 6.87 & 7.54 & NS \\
\hline $\mathrm{P}-\mathrm{M} 1, \mathrm{mg} \mathrm{kg}^{-1}$ & 20.06 & 20.21 & 20.41 & 19.95 & 19.32 & 19.99 & NS \\
\hline $\mathrm{K}, \mathrm{cmol}_{\mathrm{c}} \mathrm{kg}^{-1}$ & 0.12 & 0.11 & 0.11 & 0.10 & 0.08 & 0.10 & NS \\
\hline $\mathrm{Ca}, \mathrm{cmol}_{\mathrm{c}} \mathrm{kg}^{-1}$ & 1.55 & 1.55 & 1.49 & 1.46 & 1.27 & 1.46 & NS \\
\hline $\mathrm{Mg}, \mathrm{Cmol}_{\mathrm{c}} \mathrm{kg}^{-1}$ & 0.78 & 0.77 & 0.75 & 0.74 & 0.68 & 0.74 & NS \\
\hline $\mathrm{Al}, \mathrm{cmol}_{\mathrm{c}} \mathrm{kg}^{-1}$ & 0.00 & 0.00 & 0.00 & 0.00 & 0.00 & 0.00 & NS \\
\hline $\mathrm{H}+\mathrm{Al}, \mathrm{cmol}_{\mathrm{c}} \mathrm{kg}^{-1}$ & 1.94 & 1.86 & 1.93 & 1.76 & 1.69 & 1.83 & NS \\
\hline $\mathrm{CEC}, \mathrm{cmol}_{\mathrm{c}} \mathrm{kg}^{-1}$ & 4.38 & 4.29 & 4.28 & 4.06 & 3.71 & 4.14 & NS \\
\hline $\mathrm{V}, \%$ & 55.96 & 57.07 & 55.04 & 57.06 & 54.79 & 55.98 & NS \\
\hline $\mathrm{S}-\mathrm{SO}_{4}, \mathrm{mg} \mathrm{kg}^{-1}$ & 5.84 & 5.59 & 5.49 & 5.27 & 5.46 & 5.53 & NS \\
\hline $\mathrm{B}, \mathrm{mg} \mathrm{kg}^{-1}$ & 0.20 & 0.19 & 0.19 & 0.17 & 0.18 & 0.19 & NS \\
\hline $\mathrm{Cu}-\mathrm{M} 1, \mathrm{mg} \mathrm{kg}^{-1}$ & 0.68 & 0.62 & 0.69 & 0.73 & 0.85 & 0.71 & NS \\
\hline $\mathrm{Fe}-\mathrm{M} 1, \mathrm{mg} \mathrm{kg}^{-1}$ & 52.00 & 48.70 & 47.13 & 44.13 & 46.50 & 47.69 & NS \\
\hline $\mathrm{Mn}-\mathrm{M} 1, \mathrm{mg} \mathrm{kg}^{-1}$ & 23.75 & 22.95 & 23.03 & 22.03 & 20.03 & 22.36 & NS \\
\hline \multicolumn{8}{|c|}{ BRS 245RR (-Gly) } \\
\hline $\mathrm{pH}, \mathrm{CaCl}_{2}$ & 5.82 & 5.85 & 5.89 & 5.67 & 5.64 & 5.59 & NS \\
\hline C, $\mathrm{g} \mathrm{kg}^{-1}$ & 7.54 & 7.02 & 6.95 & 7.27 & 7.33 & 7.34 & NS \\
\hline $\mathrm{P}-\mathrm{M} 1, \mathrm{mg} \mathrm{kg}^{-1}$ & 19.99 & 20.07 & 18.25 & 16.57 & 15.12 & 13.76 & $*$ \\
\hline $\mathrm{K}, \mathrm{cmol}_{\mathrm{c}} \mathrm{kg}^{-1}$ & 0.10 & 0.10 & 0.08 & 0.10 & 0.10 & 0.09 & NS \\
\hline $\mathrm{Ca}, \mathrm{cmol}_{\mathrm{c}} \mathrm{kg}^{-1}$ & 1.46 & 1.27 & 1.27 & 1.23 & 1.26 & 1.22 & NS \\
\hline $\mathrm{Mg}, \mathrm{cmol}_{\mathrm{c}} \mathrm{kg}^{-1}$ & 0.74 & 0.66 & 0.66 & 0.65 & 0.64 & 0.64 & NS \\
\hline $\mathrm{Al}, \mathrm{cmol}_{\mathrm{c}} \mathrm{kg}^{-1}$ & 0.00 & 0.00 & 0.00 & 0.00 & 0.00 & 0.00 & NS \\
\hline $\mathrm{H}+\mathrm{Al}, \mathrm{cmol}_{\mathrm{c}} \mathrm{kg}^{-1}$ & 1.83 & 1.72 & 1.69 & 1.88 & 1.94 & 1.98 & NS \\
\hline CEC, $\mathrm{cmol}_{\mathrm{c}} \mathrm{kg}^{-1}$ & 4.14 & 3.74 & 3.69 & 3.86 & 3.94 & 3.92 & NS \\
\hline $\mathrm{V}, \%$ & 55.98 & 54.34 & 54.54 & 51.42 & 51.06 & 49.85 & NS \\
\hline $\mathrm{S}-\mathrm{SO}_{4}, \mathrm{mg} \mathrm{kg}^{-1}$ & 5.53 & 5.35 & 5.50 & 5.78 & 5.68 & 5.58 & NS \\
\hline $\mathrm{B}, \mathrm{mg} \mathrm{kg}^{-1}$ & 0.19 & 0.19 & 0.19 & 0.22 & 0.22 & 0.24 & NS \\
\hline $\mathrm{Cu}-\mathrm{M} 1, \mathrm{mg} \mathrm{kg}^{-1}$ & 0.91 & 0.80 & 0.81 & 0.72 & 0.75 & 0.80 & NS \\
\hline $\mathrm{Fe}-\mathrm{M} 1, \mathrm{mg} \mathrm{kg}^{-1}$ & 45.53 & 43.45 & 44.15 & 44.45 & 42.43 & 44.00 & NS \\
\hline $\mathrm{Mn}-\mathrm{M} 1, \mathrm{mg} \mathrm{kg}^{-1}$ & 19.68 & 18.65 & 19.03 & 18.90 & 18.30 & 18.91 & NS \\
\hline \multicolumn{8}{|c|}{ BRS 245RR (+Gly) } \\
\hline $\mathrm{pH}, \mathrm{CaCl}_{2}$ & 5.45 & 5.64 & 5.64 & 5.53 & 5.72 & 5.59 & NS \\
\hline$C, \mathrm{~g} \mathrm{~kg}^{-1}$ & 7.77 & 7.56 & 7.35 & 7.44 & 7.03 & 7.43 & NS \\
\hline P-M1, mg kg ${ }^{-1}$ & 18.90 & 21.28 & 22.08 & 22.03 & 14.96 & 19.85 & NS \\
\hline $\mathrm{K}, \mathrm{cmol}_{\mathrm{c}} \mathrm{kg}^{-1}$ & 0.10 & 0.09 & 0.11 & 0.11 & 0.10 & 0.10 & NS \\
\hline $\mathrm{Ca}, \mathrm{cmol}_{\mathrm{c}} \mathrm{kg}^{-1}$ & 1.19 & 1.27 & 1.21 & 1.18 & 1.23 & 1.22 & NS \\
\hline $\mathrm{Mg}, \mathrm{Cmol}_{\mathrm{c}} \mathrm{kg}^{-1}$ & 0.64 & 0.67 & 0.66 & 0.63 & 0.65 & 0.65 & NS \\
\hline $\mathrm{Al}, \mathrm{cmol}_{\mathrm{c}} \mathrm{kg}^{-1}$ & 0.00 & 0.00 & 0.00 & 0.00 & 0.00 & 0.00 & NS \\
\hline $\mathrm{H}+\mathrm{Al}, \mathrm{cmol}_{\mathrm{c}} \mathrm{kg}^{-1}$ & 2.14 & 1.96 & 1.89 & 1.97 & 1.77 & 1.95 & NS \\
\hline $\mathrm{CEC}, \mathrm{cmol}_{\mathrm{c}} \mathrm{kg}^{-1}$ & 4.07 & 3.99 & 3.87 & 3.89 & 3.74 & 3.91 & NS \\
\hline $\mathrm{V}, \%$ & 47.48 & 51.03 & 51.14 & 49.37 & 52.68 & 50.34 & NS \\
\hline $\mathrm{S}-\mathrm{SO}_{4}, \mathrm{mg} \mathrm{kg}^{-1}$ & 5.39 & 5.23 & 4.98 & 4.84 & 4.97 & 5.08 & NS \\
\hline $\mathrm{B}, \mathrm{mg} \mathrm{kg}^{-1}$ & 0.28 & 0.27 & 0.27 & 0.26 & 0.22 & 0.26 & NS \\
\hline $\mathrm{Cu}-\mathrm{M} 1, \mathrm{mg} \mathrm{kg}{ }^{-1}$ & 1.05 & 0.99 & 0.99 & 0.93 & 0.65 & 0.92 & NS \\
\hline $\mathrm{Fe}-\mathrm{M} 1, \mathrm{mg} \mathrm{kg}^{-1}$ & 44.33 & 43.00 & 43.70 & 45.65 & 45.15 & 44.37 & NS \\
\hline $\mathrm{Mn}-\mathrm{M} 1, \mathrm{mg} \mathrm{kg}^{-1}$ & 19.23 & 18.20 & 16.65 & 16.63 & 15.83 & 17.31 & NS \\
\hline
\end{tabular}

BRS 245RR $(+\mathrm{Gly})-\hat{y}=0.555+0.151^{\star} x, R^{2}=0.66, P \leq 0.05$;

Total- $\hat{y}=0.491+0.182^{\star} x, R^{2}=0.41, P \leq 0.05$.

DTPA-TEA, pH 7.3 Extractant

BRS 133- $\hat{y}=0.488+0.115^{*} x, R^{2}=0.44, P \leq 0.05$;

BRS 245RR (-Gly)- $\hat{y}=0.416+0.126^{*} x, R^{2}=0.50, P \leq 0.05$;

BRS 245RR (+Gly) - $\hat{y}=0.561+0.092^{*} x, R^{2}=0.57, P \leq 0.05$;

Total- $\hat{y}=0.489+0.111^{\star} x, R^{2}=0.48, P \leq 0.05$. 
Table 2. Chemical properties of an Orthic Ultisol as influenced by zinc rates within the NGM-BRS 133 and GM-BRS 245RR [without (Gly) and with (+Gly) glyphosate application] soybean cultivars in Paraná State, Brazil.

\begin{tabular}{|c|c|c|c|c|c|c|c|}
\hline \multirow[b]{2}{*}{ Soil properties } & \multicolumn{6}{|c|}{ Zinc, $\mathrm{kg} \mathrm{ha}^{-1}$} & \multirow[b]{2}{*}{ F-test } \\
\hline & 0 & 3 & 6 & 9 & 12 & Average & \\
\hline \multicolumn{8}{|c|}{ BRS 133} \\
\hline $\mathrm{pH}, \mathrm{CaCl}_{2}$ & 5.12 & 5.25 & 5.13 & 5.33 & 5.17 & 5.20 & NS \\
\hline$C, \mathrm{~g} \mathrm{~kg}^{-1}$ & 20.54 & 23.35 & 23.85 & 23.91 & 23.02 & 22.93 & NS \\
\hline P-M1, mg kg ${ }^{-1}$ & 1.91 & 3.80 & 2.80 & 4.12 & 5.79 & 3.68 & * \\
\hline $\mathrm{K}, \mathrm{cmol}_{\mathrm{c}} \mathrm{kg}^{-1}$ & 0.20 & 0.22 & 0.22 & 0.22 & 0.21 & 0.21 & NS \\
\hline $\mathrm{Ca}, \mathrm{cmol}_{\mathrm{c}} \mathrm{kg}^{-1}$ & 2.70 & 2.95 & 2.90 & 3.26 & 2.79 & 2.92 & NS \\
\hline $\mathrm{Mg}, \mathrm{cmol}_{\mathrm{c}} \mathrm{kg}^{-1}$ & 1.51 & 1.68 & 1.55 & 1.68 & 1.65 & 1.61 & NS \\
\hline $\mathrm{Al}, \mathrm{cmol}_{\mathrm{c}} \mathrm{kg}^{-1}$ & 0.08 & 0.06 & 0.06 & 0.01 & 0.02 & 0.05 & NS \\
\hline $\mathrm{H}+\mathrm{Al}, \mathrm{cmol}_{\mathrm{c}} \mathrm{kg}^{-1}$ & 5.34 & 5.01 & 5.19 & 4.69 & 5.06 & 5.06 & NS \\
\hline CEC, $\mathrm{cmol}_{\mathrm{C}} \mathrm{kg}^{-1}$ & 9.74 & 9.86 & 9.86 & 9.85 & 9.71 & 9.80 & NS \\
\hline $\mathrm{V}, \%$ & 45.63 & 49.16 & 47.39 & 52.15 & 47.79 & 48.42 & NS \\
\hline $\mathrm{S}-\mathrm{SO}_{4}, \mathrm{mg} \mathrm{kg}^{-1}$ & 12.84 & 10.47 & 13.38 & 19.68 & 14.18 & 14.11 & NS \\
\hline $\mathrm{B}, \mathrm{mg} \mathrm{kg}^{-1}$ & 0.36 & 0.36 & 0.40 & 0.45 & 0.37 & 0.39 & NS \\
\hline $\mathrm{Cu}-\mathrm{M} 1, \mathrm{mg} \mathrm{kg}^{-1}$ & 1.87 & 1.73 & 1.76 & 1.80 & 2.01 & 1.83 & NS \\
\hline $\mathrm{Fe}-\mathrm{M} 1, \mathrm{mg} \mathrm{kg}^{-1}$ & 51.60 & 48.83 & 48.38 & 48.53 & 51.75 & 49.82 & NS \\
\hline $\mathrm{Mn}-\mathrm{M} 1, \mathrm{mg} \mathrm{kg}^{-1}$ & 10.35 & 10.95 & 11.58 & 12.60 & 11.70 & 11.44 & NS \\
\hline \multicolumn{8}{|c|}{ BRS 245RR (-Gly) } \\
\hline $\mathrm{pH}, \mathrm{CaCl}_{2}$ & 5.62 & 5.13 & 5.42 & 4.98 & 5.31 & 5.29 & NS \\
\hline$C, \mathrm{~g} \mathrm{~kg}^{-1}$ & 22.96 & 23.14 & 22.91 & 21.27 & 24.06 & 22.87 & NS \\
\hline $\mathrm{P}-\mathrm{M} 1, \mathrm{mg} \mathrm{kg}^{-1}$ & 1.77 & 1.99 & 5.11 & 4.11 & 6.07 & 3.81 & $*$ \\
\hline $\mathrm{K}, \mathrm{cmol}_{\mathrm{c}} \mathrm{kg}^{-1}$ & 0.20 & 0.22 & 0.22 & 0.17 & 0.20 & 0.20 & NS \\
\hline $\mathrm{Ca}, \mathrm{cmol}_{\mathrm{c}} \mathrm{kg}^{-1}$ & 3.45 & 2.74 & 2.95 & 2.46 & 2.97 & 2.91 & NS \\
\hline $\mathrm{Mg}, \mathrm{cmol}_{\mathrm{c}} \mathrm{kg}^{-1}$ & 2.00 & 1.44 & 1.78 & 1.34 & 1.72 & 1.66 & NS \\
\hline $\mathrm{Al}, \mathrm{cmol}_{\mathrm{c}} \mathrm{kg}^{-1}$ & 0.00 & 0.10 & 0.06 & 0.08 & 0.08 & 0.06 & NS \\
\hline $\mathrm{H}+\mathrm{Al}, \mathrm{cmol}_{\mathrm{c}} \mathrm{kg}^{-1}$ & 4.03 & 5.32 & 4.68 & 5.57 & 5.00 & 4.92 & NS \\
\hline CEC, $\mathrm{cmol}_{\mathrm{C}} \mathrm{kg}^{-1}$ & 9.68 & 9.71 & 9.62 & 9.54 & 9.88 & 9.69 & NS \\
\hline $\mathrm{V}, \%$ & 58.36 & 45.50 & 51.45 & 41.55 & 49.63 & 49.30 & NS \\
\hline $\mathrm{S}-\mathrm{SO}_{4}, \mathrm{mg} \mathrm{kg}^{-1}$ & 12.38 & 13.61 & 13.43 & 14.09 & 12.23 & 13.15 & NS \\
\hline $\mathrm{B}, \mathrm{mg} \mathrm{kg}^{-1}$ & 0.30 & 0.34 & 0.30 & 0.46 & 0.36 & 0.35 & NS \\
\hline $\mathrm{Cu}-\mathrm{M} 1, \mathrm{mg} \mathrm{kg}^{-1}$ & 1.67 & 1.86 & 1.76 & 1.92 & 1.94 & 1.83 & NS \\
\hline $\mathrm{Fe}-\mathrm{M} 1, \mathrm{mg} \mathrm{kg}^{-1}$ & 40.55 & 54.60 & 51.73 & 51.05 & 67.85 & 53.16 & NS \\
\hline $\mathrm{Mn}-\mathrm{M} 1, \mathrm{mg} \mathrm{kg}^{-1}$ & 12.13 & 11.65 & 12.13 & 10.23 & 15.08 & 12.24 & NS \\
\hline \multicolumn{8}{|c|}{ BRS 245RR (+Gly) } \\
\hline $\mathrm{pH}, \mathrm{CaCl}_{2}$ & 5.24 & 5.28 & 5.22 & 5.11 & 5.29 & 5.23 & NS \\
\hline$C, \mathrm{~g} \mathrm{~kg}^{-1}$ & 22.45 & 23.21 & 23.88 & 22.44 & 22.00 & 22.80 & NS \\
\hline P-M1, mg kg ${ }^{-1}$ & 2.28 & 1.76 & 2.69 & 1.66 & 2.19 & 2.12 & NS \\
\hline $\mathrm{K}, \mathrm{cmol}_{\mathrm{c}} \mathrm{kg}^{-1}$ & 0.17 & 0.19 & 0.16 & 0.16 & 0.18 & 0.17 & NS \\
\hline $\mathrm{Ca}, \mathrm{cmol}_{\mathrm{c}} \mathrm{kg}^{-1}$ & 2.76 & 2.99 & 2.71 & 2.65 & 3.00 & 2.82 & NS \\
\hline $\mathrm{Mg}, \mathrm{cmol}_{\mathrm{c}} \mathrm{kg}^{-1}$ & 1.57 & 1.66 & 1.63 & 1.53 & 1.74 & 1.63 & NS \\
\hline $\mathrm{Al}, \mathrm{cmol}_{\mathrm{c}} \mathrm{kg}^{-1}$ & 0.12 & 0.03 & 0.05 & 0.00 & 0.03 & 0.05 & NS \\
\hline $\mathrm{H}+\mathrm{Al}, \mathrm{cmol}_{\mathrm{c}} \mathrm{kg}^{-1}$ & 5.08 & 4.80 & 5.10 & 5.25 & 4.75 & 5.00 & NS \\
\hline CEC, $\mathrm{cmol}_{\mathrm{C}} \mathrm{kg}^{-1}$ & 9.57 & 9.64 & 9.60 & 9.58 & 9.67 & 9.61 & NS \\
\hline $\mathrm{V}, \%$ & 47.42 & 50.43 & 46.96 & 45.16 & 50.91 & 48.18 & NS \\
\hline $\mathrm{S}-\mathrm{SO}_{4}, \mathrm{mg} \mathrm{kg}^{-1}$ & 15.79 & 13.88 & 16.28 & 13.07 & 15.67 & 14.94 & NS \\
\hline $\mathrm{B}, \mathrm{mg} \mathrm{kg}^{-1}$ & 0.45 & 0.35 & 0.40 & 0.38 & 0.34 & 0.38 & NS \\
\hline $\mathrm{Cu}-\mathrm{M} 1, \mathrm{mg} \mathrm{kg}{ }^{-1}$ & 2.24 & 2.04 & 1.90 & 1.83 & 1.84 & 1.97 & NS \\
\hline $\mathrm{Fe}-\mathrm{M} 1, \mathrm{mg} \mathrm{kg}^{-1}$ & 63.45 & 58.88 & 51.58 & 50.45 & 48.20 & 54.51 & NS \\
\hline $\mathrm{Mn}-\mathrm{M} 1, \mathrm{mg} \mathrm{kg}^{-1}$ & 11.85 & 12.15 & 11.53 & 10.58 & 11.25 & 11.47 & NS \\
\hline
\end{tabular}

b) Ponta Grossa, Paraná State (Orthic Ferralsol)

Mehlich 1 extractant

BRS 133- $\hat{y}=0.515+0.263^{*} x, R^{2}=0.58, P \leq 0.05$

BRS 245RR (-Gly) $-\hat{y}=0.919+0.185^{\star} x, R^{2}=0.40, P \leq 0.05$;

BRS 245RR (+Gly) $-\hat{y}=1.019+0.123^{\star} x, R^{2}=0.55, P \leq 0.05$;

Total- $\hat{y}=0.817+0.190^{\star} x, R^{2}=0.44, P \leq 0.05$.

DTPA-TEA, pH 7.3 extractant 

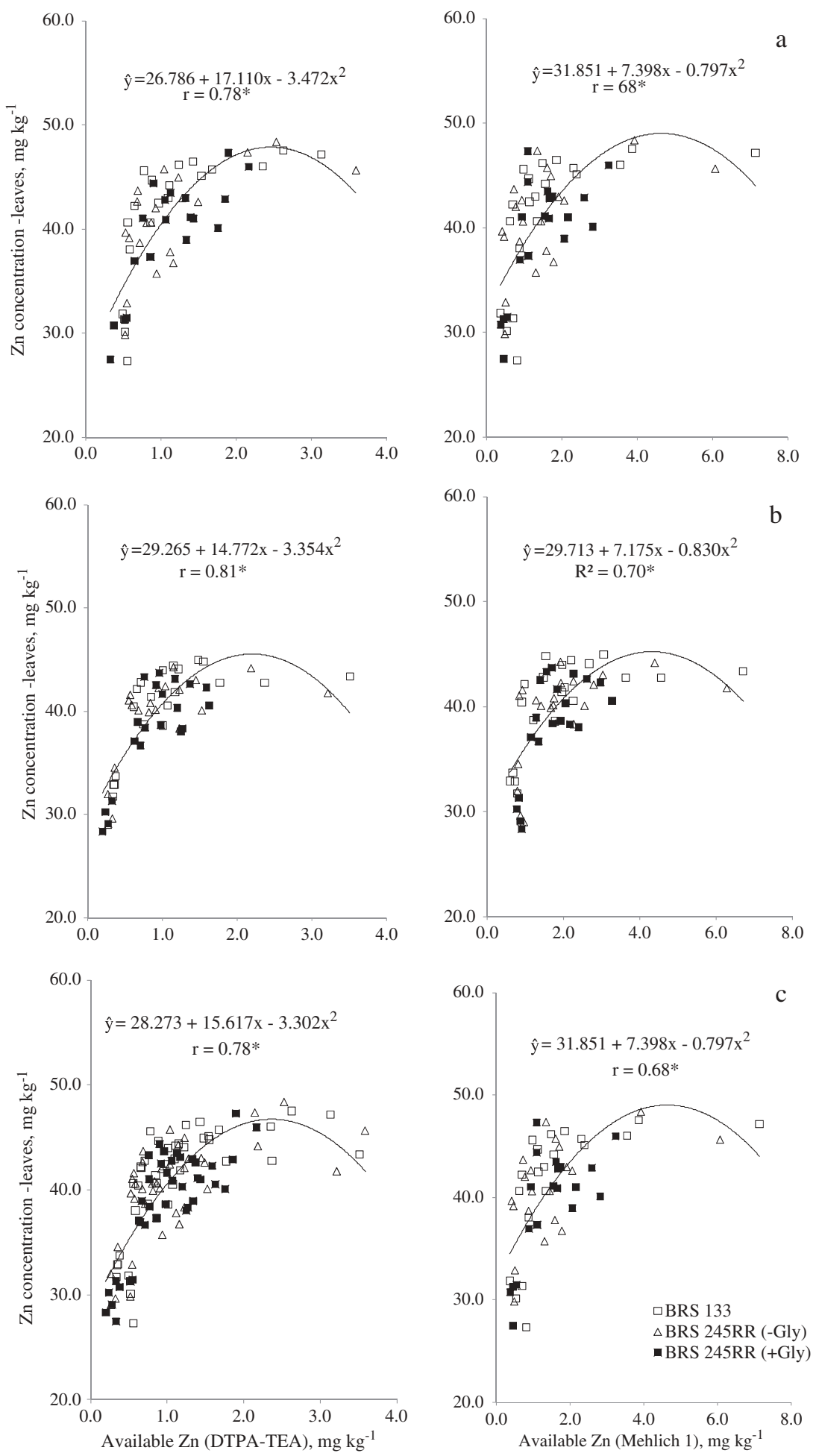

Figure 1. Relationship between the concentration of $\mathrm{Zn}$ in the leaf and in the soil obtained with Mehlich 1 and DTPA-TEA extractants in aTypic Quartzipsamment (a), an Orthic Ferralsol (b) and the sum of the two types of soils (c). *Significant at the $5 \%$ probability. 

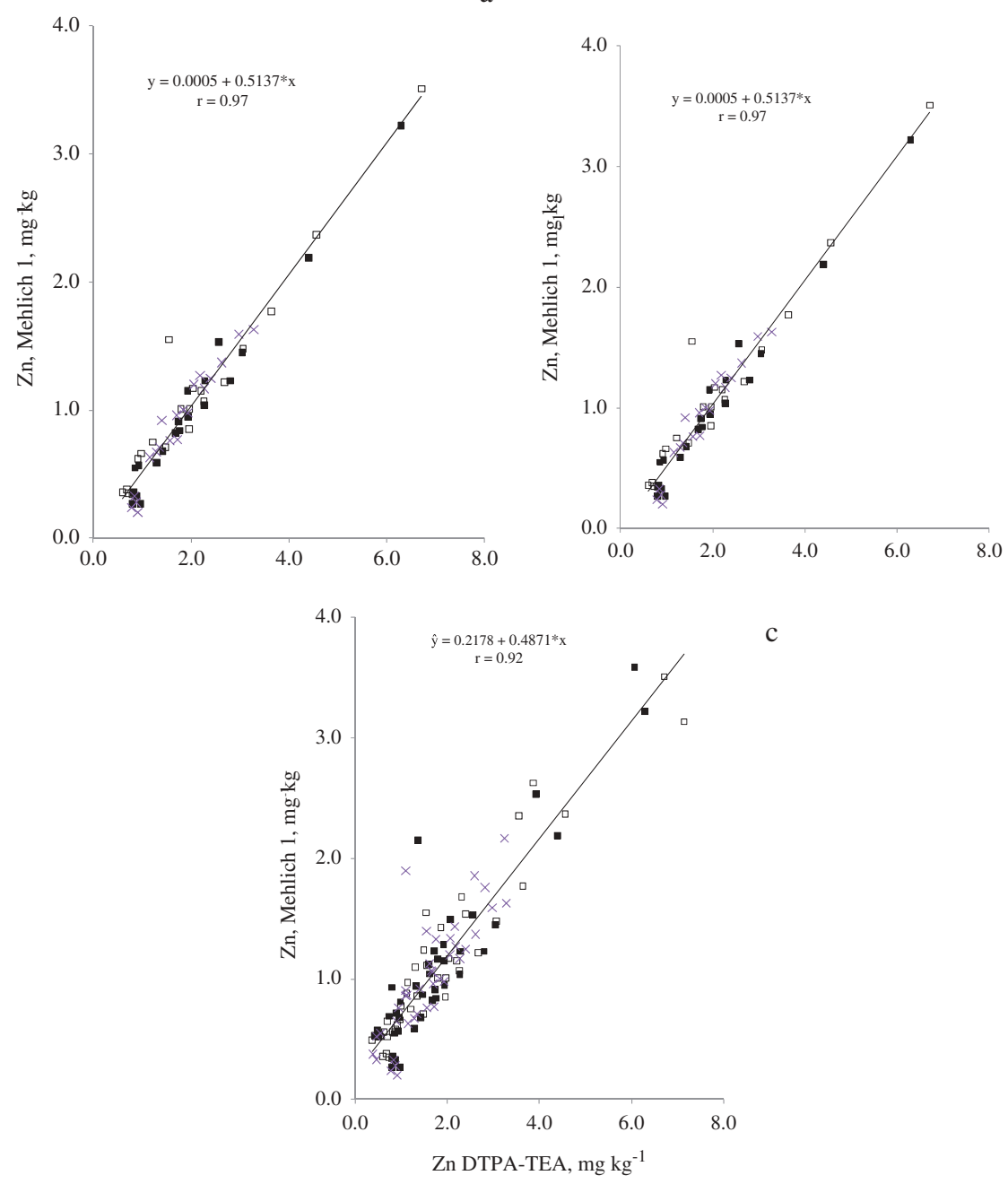

Figure 2. Relationship between Mehlich 1 and DTPA-TEA, 7.3 extractants for available Zn in Typic Quartzipsamment (a), Orthic Ultisol (b), and the sum of the two types of soils (c). *Significant at the $5 \%$ probability.

BRS $133-\hat{y}=0.361+0.125^{\star} x, R^{2}=0.51, P \leq 0.05$;

BRS 245RR (-Gly) - $\hat{y}=0.386+0.103^{*} x, R^{2}=0.40, P \leq 0.05$;

BRS 245RR (+Gly)- $\hat{y}=0.403+0.082^{*} x, R^{2}=0.70, P \leq 0.05$;

Total $-\hat{y}=0.383+0.104^{*} x, R^{2}=0.47, P \leq 0.05$.

The values obtained under the two climate and soil conditions indicate that Mehlich 1 (M1) and DTPATEA, 7.3 extractants provide similar information on the available $\mathrm{Zn}$ concentration in the soil. Regarding the selection of the extracting solutions, it should be considered, that although the coefficient values of M1 extractant are lower than those of DTPA-TEA, it can extract the available $\mathrm{Zn}$ and be used to determine P, $\mathrm{K}^{+}, \mathrm{Ca}^{2+}, \mathrm{Mg}^{2+}, \mathrm{Cu}, \mathrm{Fe}$, and $\mathrm{Mn}$ concentration in the same extract (Moreira, Moraes, and Fageria 2015; Oliveira et al. 2003). 


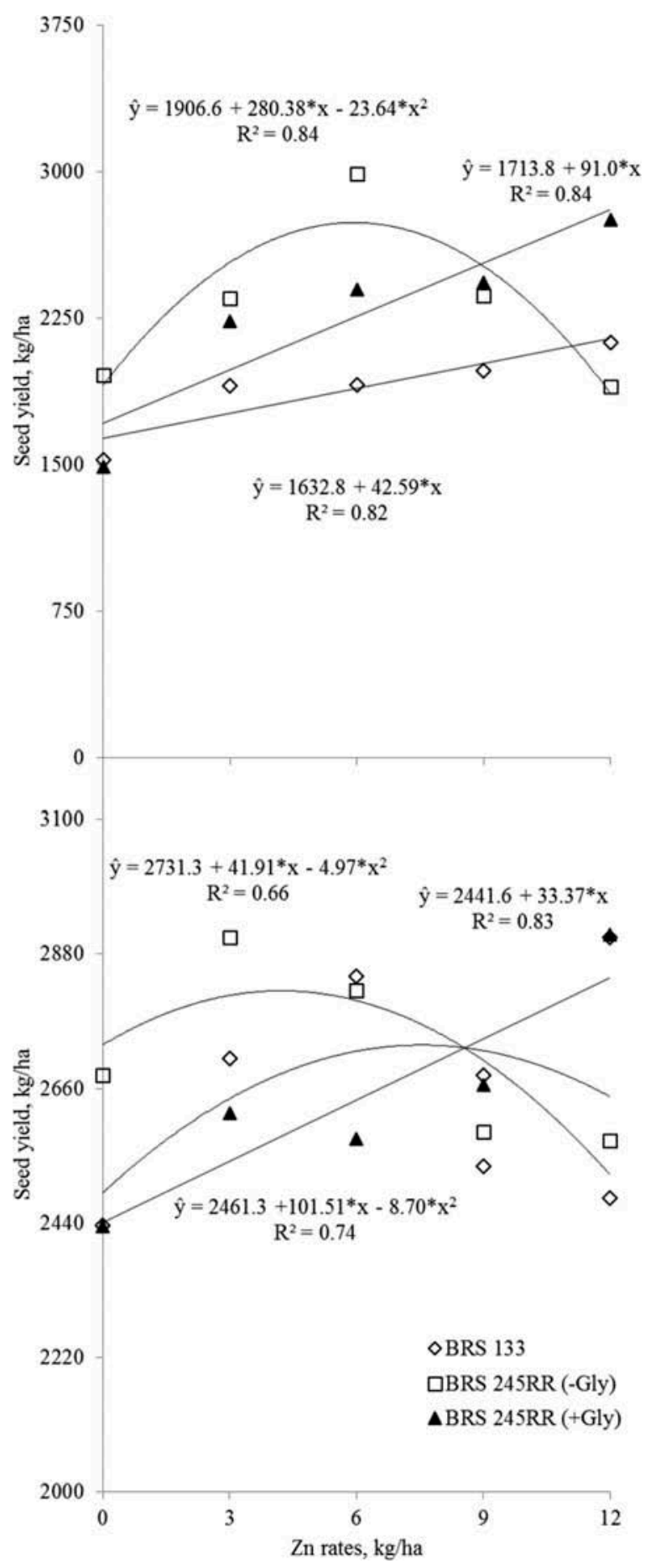

Figure 3. Effect of $\mathrm{Zn}$ rates on seed yield (SY) of the BRS 133 and BRS 245RR [with (+Gly) and without (-Gly) glyphosate application] soybean varieties cultivated in a Typic Quatzipsamment (a) and an Ortic Ultisol (b). *Significant at the $5 \%$ of probability. 


\section{Seed yield}

The absence of glyphosate caused quadratic effect in SY, with the highest estimated yields obtained with the application of $12 \mathrm{~kg} \mathrm{ha}^{-1}$ (BRS 133) and $5.9 \mathrm{~kg} \mathrm{ha}^{-1}$ [BRS 245RR (-Gly)] of Zn in a Typic Quartzipsamment and $6.1 \mathrm{~kg} \mathrm{ha}^{-1}$ (BRS 133) and $4.2 \mathrm{~kg} \mathrm{ha}^{-1}$ [BRS 245RR (-Gly)] in an Orthic Ferralsol, respectively, while in treatment BRS 245RR (+Gly), there was a positive linear effect in the two types of soil, with the highest yield obtained with the $12 \mathrm{~kg} \mathrm{ha}^{-1}$ of $\mathrm{Zn}$ application (Figure 3). This fact demonstrates the possible inhibitory effect in $\mathrm{Zn}$ uptake caused by glyphosate application described by Serra et al. (2011), reducing the possible phytotoxic effect of high $\mathrm{Zn}$ rates in the soil to meet the nutritional demands of plants, which was also reported by Zobiole et al. (2012) in glyphosate-resistant (GR2) second generation soybean crop.

The introduction of the gene that confers glyphosate resistance did not affect SY, and the GM variety had the highest SY compared to convention variety (BRS 133), with estimated values of $2,738.0 \mathrm{~kg} \mathrm{ha}^{-1}$ (Gly), 2,815.8 kg ha $\mathrm{kg}^{-1}$ (Gly) and 2,143.9 kg ha ${ }^{-1}$ in NGM variety in a Typic Quartzipsamment and 2,819.6 $\mathrm{kg} \mathrm{ha}^{-1}$ in (-Gly), 2,842.0 $\mathrm{kg} \mathrm{ha}^{-1}$ (+Gly) and 2,757.4 $\mathrm{kg} \mathrm{ha}^{-1}$ in NGM in an Orthic Ferralsol. The highest yield reported for BRS $245 \mathrm{RR}+\mathrm{Gly}$ (Figure 3) can be probably due to the more efficient weed control. Rosolem et al. (2010) and Gonçalves et al. (2014) also found that the presence of the gene that confers resistance to glyphosate herbicide (RR) in the plant did not affect soybean development and yield.

\section{Yield components}

Plant height, chlorophyll content, number of pods per plant (NPP), number of seeds per pod (NSP), SDW, and 100-seed weight are shown in Table 3 . The SDW yield and NPP were affected $(P \leq 0.05)$ by $\mathrm{Zn}$ rates ant type of variety in the two crop sites, with significant interaction of varieties $\times$ rates, indicating variability

Table 3. Plant height, chlorophyll, seed per pod, pod per plant, shoot dry weight (SDW) yield and 100-seed weight of NGM-BRS 133 and GM-BRS 245RR [without (-Gly) and (+Gly) glyphosate application] soybean cultivars as influenced by Zn rates cultivated in Mato Grosso do Sul State (Typic Quartzipsamment-TQ) and Paraná States (Orthic Ultisol-OU), Brazil.

\begin{tabular}{|c|c|c|c|c|c|c|c|c|c|c|c|c|c|}
\hline \multirow[t]{3}{*}{ Cultivar } & \multirow{3}{*}{$\begin{array}{l}\text { Zn rates } \\
\mathrm{kg} \mathrm{ha}^{-1}\end{array}$} & \multirow{2}{*}{\multicolumn{2}{|c|}{$\begin{array}{c}\text { Plant height } \\
(\mathrm{cm})\end{array}$}} & \multirow{2}{*}{\multicolumn{2}{|c|}{$\begin{array}{c}\text { Chlorophyll } \\
\left(\mathrm{mg} \mathrm{m}^{-2}\right) \\
\end{array}$}} & \multirow{2}{*}{\multicolumn{2}{|c|}{$\begin{array}{c}\text { Seed per pod } \\
(n)\end{array}$}} & \multirow{2}{*}{\multicolumn{2}{|c|}{$\begin{array}{c}\text { Pod per plant } \\
(n)\end{array}$}} & \multirow{2}{*}{\multicolumn{2}{|c|}{$\frac{\text { SDW }}{\text { (g/plant) }}$}} & \multirow{2}{*}{\multicolumn{2}{|c|}{$\frac{100 \text {-seed weight }}{(\mathrm{g})}$}} \\
\hline & & & & & & & & & & & & & \\
\hline & & $\mathrm{TQ}$ & OU & TQ & OU & TQ & OU & TQ & OU & TQ & OU & TQ & OU \\
\hline \multirow[t]{6}{*}{ BRS 133} & 0 & 44.1 & 86.6 & 369.0 & 372.2 & 1.5 & 2.5 & 36.8 & 65.3 & 19.2 & 102.1 & 15.1 & 14.2 \\
\hline & 3 & 40.9 & 85.7 & 363.6 & 381.0 & 1.8 & 2.5 & 84.3 & 75.1 & 51.0 & 125.1 & 15.1 & 14.8 \\
\hline & 6 & 40.9 & 89.9 & 354.7 & 383.9 & 2.2 & 2.4 & 78.0 & 64.5 & 34.1 & 114.2 & 14.8 & 14.8 \\
\hline & 9 & 47.0 & 86.3 & 381.7 & 377.7 & 2.0 & 2.4 & 93.7 & 61.2 & 37.7 & 92.0 & 15.0 & 14.3 \\
\hline & 12 & 45.3 & 84.5 & 386.6 & 379.0 & 1.8 & 2.5 & 59.0 & 74.2 & 24.1 & 131.3 & 14.9 & 14.6 \\
\hline & Average & $43.6 \mathrm{~b}$ & $86.6 a$ & $371.1 \mathrm{a}$ & $378.8 \mathrm{a}$ & $1.9 \mathrm{a}$ & $2.5 a$ & $70.4 c$ & $68.1 \mathrm{~b}$ & $33.2 b$ & $112.9 \mathrm{~b}$ & $15.0 \mathrm{a}$ & $14.5 \mathrm{a}$ \\
\hline & 0 & 47.1 & 84.5 & 374.0 & 388.8 & 2.1 & 2.5 & 62.7 & 82.9 & 22.0 & 150.9 & 14.0 & 14.6 \\
\hline \multirow{5}{*}{ (-Gly) } & 3 & 52.0 & 87.1 & 380.5 & 379.4 & 2.1 & 2.5 & 88.7 & 50.4 & 37.2 & 109.7 & 12.8 & 14.7 \\
\hline & 6 & 47.0 & 87.1 & 374.1 & 374.4 & 1.8 & 2.5 & 158.3 & 73.7 & 68.8 & 115.4 & 14.2 & 14.4 \\
\hline & 9 & 48.4 & 89.0 & 376.4 & 386.0 & 2.1 & 2.5 & 127.7 & 103.6 & 54.9 & 157.1 & 14.0 & 14.8 \\
\hline & 12 & 50.3 & 88.8 & 377.5 & 372.4 & 2.4 & 2.4 & 111.0 & 94.3 & 37.1 & 149.7 & 13.1 & 15.1 \\
\hline & Average & $49.0 a$ & $87.3 a$ & $376.5 a$ & $380.2 a$ & $2.1 \mathrm{a}$ & $2.5 a$ & $109.7 a$ & $81.0 a$ & $44.0 \mathrm{a}$ & $136.6 a$ & $13.6 a$ & $14.7 \mathrm{a}$ \\
\hline BRS 245RR & 0 & 47.4 & 85.2 & 381.8 & 363.4 & 2.1 & 2.4 & 85.0 & 72.1 & 31.1 & 124.0 & 13.1 & 14.7 \\
\hline \multirow[t]{5}{*}{ (+Gly) } & 3 & 47.5 & 88.2 & 395.4 & 378.1 & 2.1 & 2.5 & 115.3 & 65.0 & 49.3 & 105.8 & 13.6 & 15.1 \\
\hline & 6 & 49.4 & 85.0 & 388.8 & 377.1 & 2.2 & 2.4 & 93.7 & 59.8 & 28.5 & 103.4 & 13.7 & 14.5 \\
\hline & 9 & 46.8 & 86.6 & 373.9 & 382.2 & 2.2 & 2.4 & 67.0 & 76.3 & 23.4 & 119.1 & 13.6 & 14.7 \\
\hline & 12 & 51.0 & 88.2 & 372.3 & 365.6 & 2.3 & 2.5 & 87.7 & 66.1 & 38.8 & 107.0 & 13.4 & 14.4 \\
\hline & Average & $48.4 a$ & $86.6 a$ & $382.4 a$ & $373.3 a$ & $2.2 \mathrm{a}$ & $2.4 a$ & $89.7 \mathrm{~b}$ & $67.9 \mathrm{~b}$ & $34.2 b$ & $111.9 \mathrm{~b}$ & $13.5 a$ & $14.7 \mathrm{a}$ \\
\hline \multicolumn{14}{|c|}{ 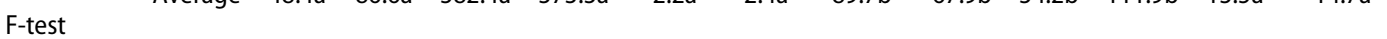 } \\
\hline Cultivar (a) & & * & NS & NS & NS & NS & NS & * & * & * & * & NS & NS \\
\hline Rates (b) & & NS & NS & NS & NS & NS & NS & * & * & * & * & NS & NS \\
\hline$a \times b$ & & NS & NS & NS & NS & NS & NS & * & * & * & * & NS & NS \\
\hline CV (\%) & & 16.4 & 17.6 & 22.1 & 19.7 & 17.2 & 16.4 & 12.1 & 18.6 & 19.8 & 22.1 & 20.7 & 14.2 \\
\hline
\end{tabular}

\footnotetext{
*, NS Significant at the $5 \%$ probability levels, respectively. CV-coefficient of variation. Cultivar-NGM BRS 133 and GM BRS 245 RR without (-Gly) and with (+Gly) glyphosate application.

Notes. Means followed by the same letter in the same column are not significantly different at the $5 \%$ probability by the ScottKnott test.
} 
between soybean varieties and glyphosate application or non-application. It was also found that glyphosate use reduced, in average, the SDW yield, but did not affect SY, which was also observed for NPP (Figure 3). Regarding plant height, when soybean was grown in Typic Quartzipsamment, variety BRS 245RR was significantly larger than BRS 133, which did not occur in the crop grown in Orthic Ferralsol, despite its 84.6\% larger height (Table 3). This difference in plant height between the two sites is possibly due to the sensitivity of both varieties to latitude variation $\left(4.5^{\circ}\right)$, which resulted in poorer development and lower size of the plants (Xavier et al. 2008).

Unlike the findings of Zobiole et al. (2012), chlorophyll content in soybean leaves was not affected by the introduction of the gene that confers glyphosate resistance, and glyphosate rates for each variety and site ranged from 371.1 to $380.2 \mathrm{mg} \mathrm{m}^{-2}$ (Table 3). The 100 seed weight was affected by the treatments (Table 3) and ranged from 12.8 to $15.1 \mathrm{~g}$, which is lower than the value of $15.3 \mathrm{~g}$ obtained by Fageria et al. (2014) in a crop grown in an Oxisol of 'Cerrado' with variety BRS 7860. According to Baligar, Fageria, and $\mathrm{He}$ (2001), genetic and environmental factors are the main explanations for the differences observed in these variables.

\section{Foliar Nutrient concentration}

There was no significant interaction between varieties $\times \mathrm{Zn}$ rates on the foliar $\mathrm{N}, \mathrm{P}, \mathrm{K}, \mathrm{Ca}, \mathrm{Mg}, \mathrm{S}, \mathrm{B}$, $\mathrm{Cu}, \mathrm{Fe}, \mathrm{Mn}$, and $\mathrm{Zn}$ concentration in the plants, in the two crop sites (Table 4). Zn rates caused a quadratic effect on foliar $\mathrm{Zn}$ concentration and lack of effect resulting from the application (+Gly) or non-application (-Gly) of glyphosate, with the highest estimated concentrations of 44.7, 43.1, and $43.9 \mathrm{mg} \mathrm{kg}^{-1}$ obtained with rates 9.8, 8.7, and $9.2 \mathrm{~kg} \mathrm{ha}^{-1}$ in a Typic Quartzipsamment, Orthic Ferralsol, and in the average of the two soils, respectively (Figure 4). There were differences between the varieties for foliar $\mathrm{K}, \mathrm{Ca}, \mathrm{S}, \mathrm{B}, \mathrm{Fe}, \mathrm{Mn}$, and $\mathrm{Zn}$ concentration in soybean grown in a Typic Quartzipsamment, and in $\mathrm{Ca}, \mathrm{S}, \mathrm{B}, \mathrm{Cu}, \mathrm{Fe}$, and $\mathrm{Mn}$ concentration for soybean grown in an Orthic Ferralsol (Figure 4 and Table 4). Despite these adequate soil levels (Tables 1 and 2), the application of glyphosate caused an average reduction of $9.8 \%, 6.2 \%, 6.7 \%$, and $14.5 \%$ in the $\mathrm{Ca}, \mathrm{B}, \mathrm{Fe}$, and $\mathrm{Mn}$ concentration (Table 4). Similar findings regarding the negative glyphosate effects on the uptake of some nutrients were also reported by Cakmak et al. (2009), Duke et al. (2012), and Zobiole et al. (2012). For Cakmak et al. (2009), the high sensitivity of reproductive organs to glyphosate could partially explain the lower $\mathrm{Ca}$ and $\mathrm{B}$ uptake by the plants.

The negative effects of glyphosate application on the Fe and Mn uptake (Table 4) were also described by Eker et al. (2006), Cakmak et al. (2009), Serra et al. (2011), and Duke et al. (2012), who report that, despite the introduction of the gene that confers glyphosate resistance, the herbicide acts in the chikimic acid pathway, impairing the synthesis of phenolic compounds such as phenylalanine, and $\mathrm{Mn}$ participates in this synthesis. As for $\mathrm{Fe}$, it inhibits the action of the ferric reductase enzyme on the roots, reducing the uptake of the nutrient, among other things (Cakmak et al. 2009). The application of glyphosate did not change foliar concentrations (Figure 4). Despite the findings described by Serra et al. (2011) and Zobiole et al. (2012) concerning the negative effects of the glyphosate use on nutrient uptake, other studies indicate that mineral nutrition in GM plants is not affected by the glyphosate application (Duke et al. 2012; Gonçalves et al. 2014; Rosolem et al. 2010)

Despite the harmful effects observed with or without the glyphosate application, except for $\mathrm{Zn}$ at the rate of $0 \mathrm{~kg} \mathrm{ha}^{-1}$ (control) on soybean grown in a Typic Quartzipsamment that showed visual symptoms of nutrient deficiency (Figure 5). N, P, K, Ca, Mg, S, B, Cu, Fe, and $\mathrm{Mn}$ concentration were within the 45.0 to $50.0 \mathrm{~g} \mathrm{~kg}^{-1}$ of $\mathrm{N}, 2.5$ to $5.0 \mathrm{~g} \mathrm{~kg}^{-1}$ of $\mathrm{P}, 17.0$ to $25.0 \mathrm{~g} \mathrm{~kg}^{-1}$ of K, 3.5 to $20.0 \mathrm{~g} \mathrm{~kg}^{-1}$ of $\mathrm{Ca}, 2.5$ to $10.0 \mathrm{~g} \mathrm{~kg}^{-1}$ of $\mathrm{Mg}, 2.0$ to $4.0 \mathrm{~g} \mathrm{~kg}^{-1}$ of $\mathrm{S}, 20$ to $55 \mathrm{mg} \mathrm{kg}^{-1}$ of $\mathrm{B}, 6$ to $14 \mathrm{mg} \mathrm{kg}^{-1}$ of $\mathrm{Cu}, 50$ to $350 \mathrm{mg} \mathrm{kg}^{-1}$ of $\mathrm{Fe}, 20$ to $100 \mathrm{mg} \mathrm{kg}^{-1}$ of $\mathrm{Mn}$ and 20 to $50 \mathrm{mg} \mathrm{kg}^{-1}$ of $\mathrm{Zn}$ concentration considered suitable by TPS (2013) for soybean cultivation. 


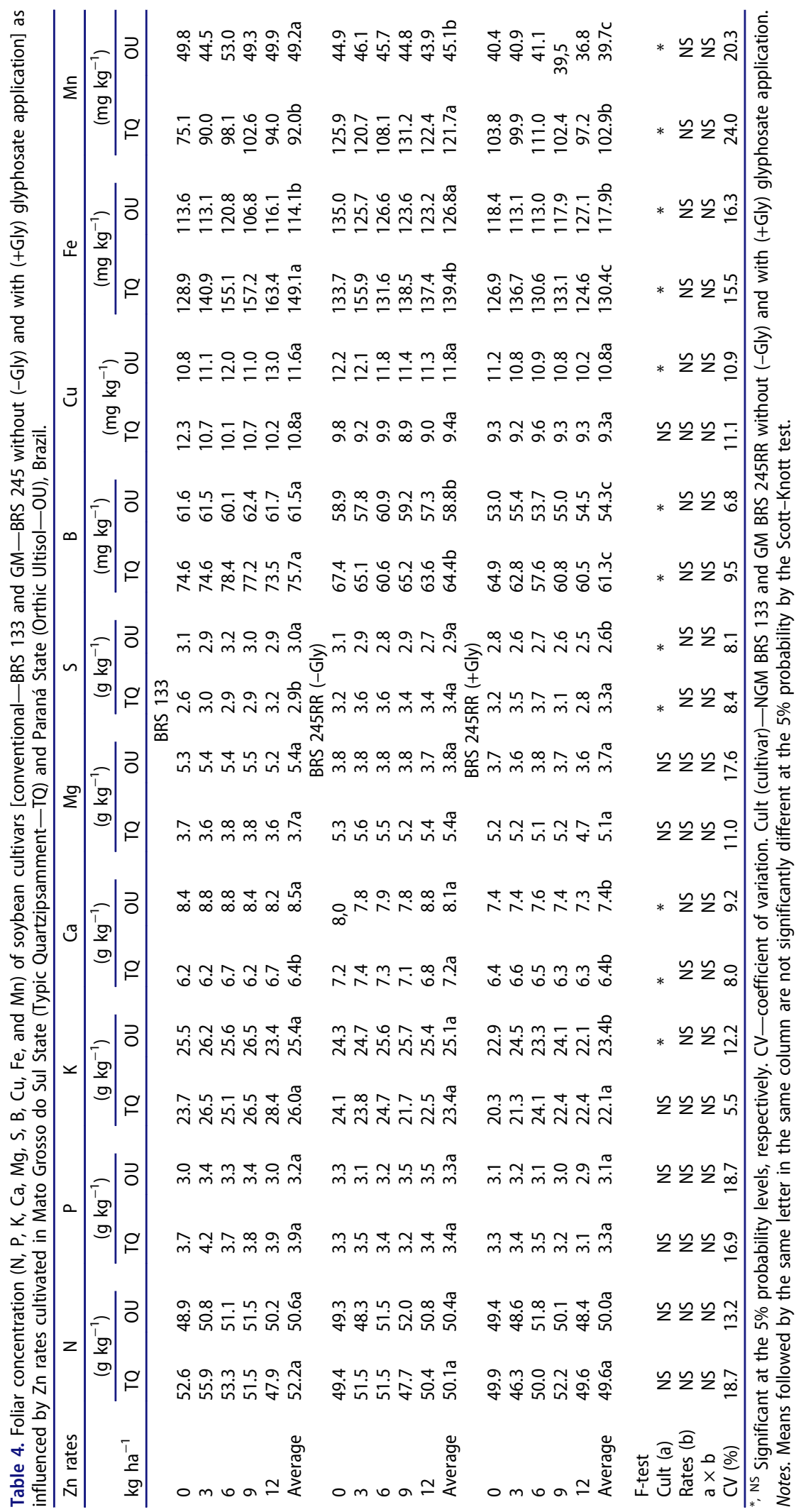


a
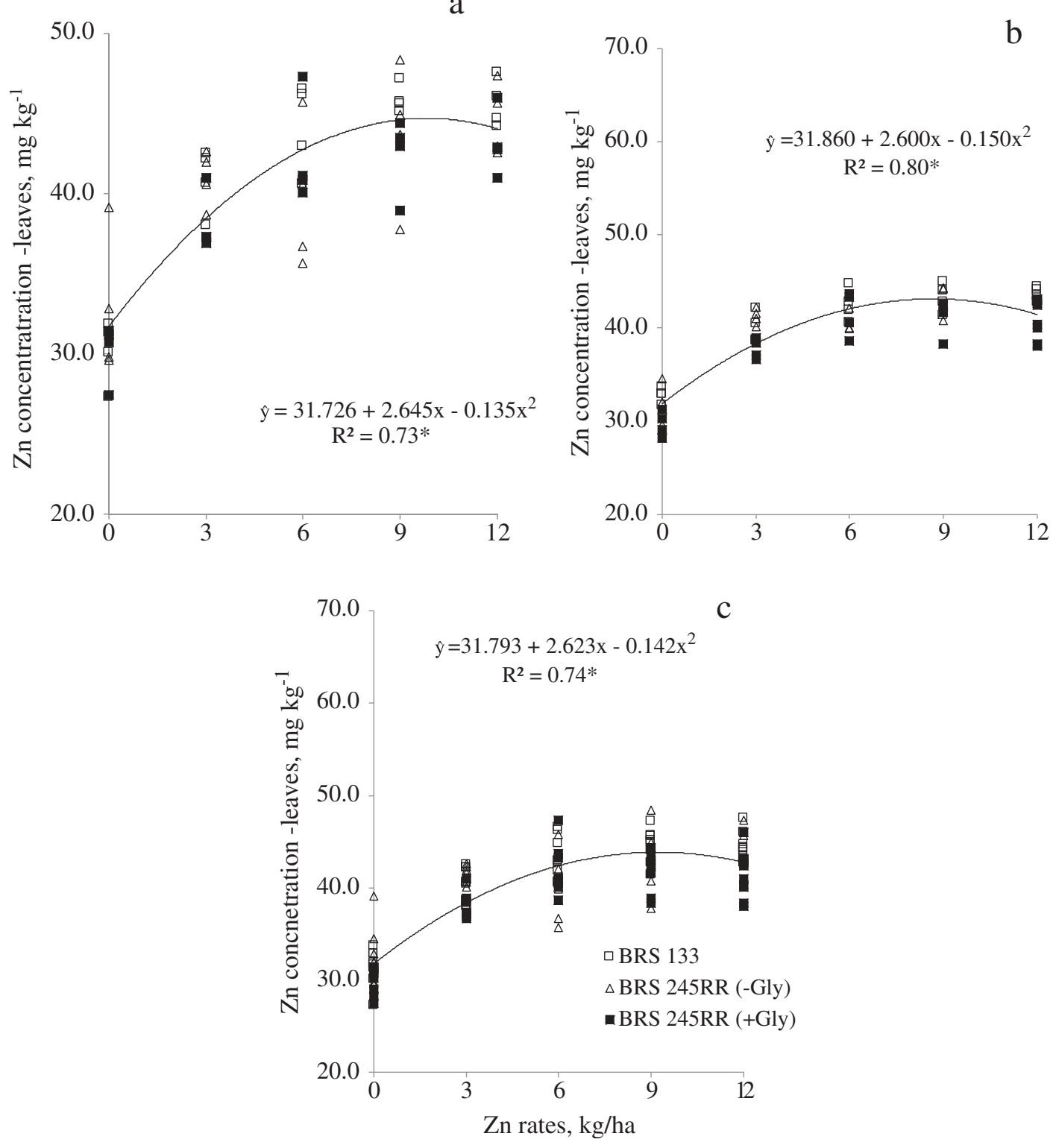

Figure 4. Effect of Zn rates on Zn concentration in BRS 133 and BRS 245RR [with (+Gly) and without (-Gly) glyphosate application] in soybean varieties cultivated in a Typic Quartzipsamment (a), an Orthic Ultisol (b), and the sum of the two soils (c). *Significant at the $5 \%$ probability.

\section{Conclusions}

Several authors have reported negative effects resulting from the glyphosate use, even in GM soybean. However, few studies investigate the effects of the herbicide on efficiency use of $\mathrm{Zn}$ by plants. The crops grown in a Typic Quartzipsamment and an Orthic Ferralsol showed that Mehlich 1 and DTPA-TEA, pH 7.3 extractants effectively determined the available $\mathrm{Zn}$ in soil. The highest estimated yields were obtained with of $12.7 \mathrm{~kg} \mathrm{ha}^{-1}$ (BRS 133) and $5.9 \mathrm{~kg} \mathrm{ha}^{-1}$ in BRS 245RR (-Gly) applications in a Typic Quartzipsamment (Mato Grosso do Sul State) and $6.1 \mathrm{~kg} \mathrm{ha}^{-1}$ and $4.2 \mathrm{~kg} \mathrm{ha}^{-1}$ in an Orthic Ferralsol (Parana State), respectively, while in the treatment BRS 245RR (+Gly), a linear 


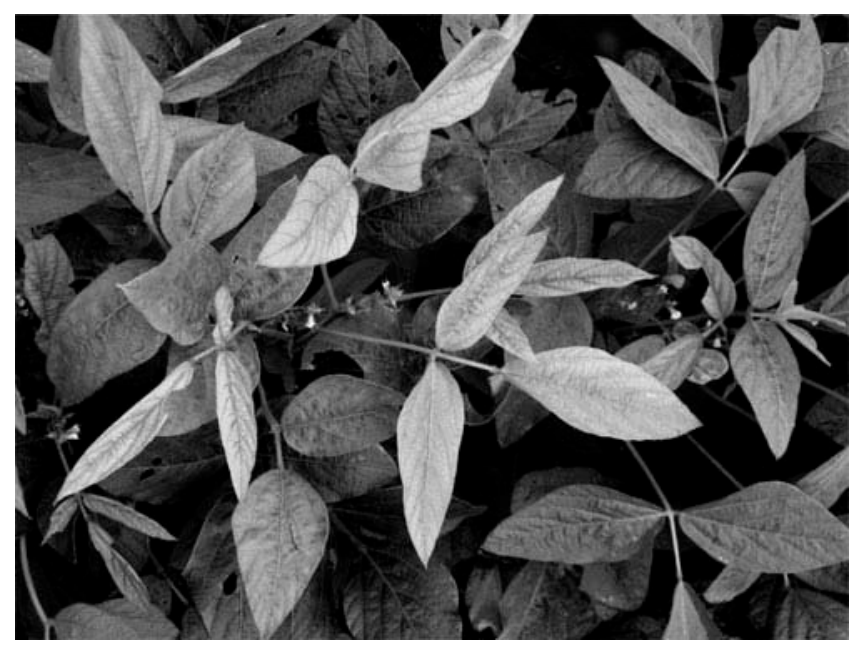

Figure 5. Symptoms of zinc ( $\mathrm{Zn}$ ) deficiency in soybean leaves grown in a Typic Quartzipsamment (Mato Grosso do Sul State) without $\mathrm{Zn}$ application.

effect was observed, and so the intersection point of maximum SY was not reached with the application of up to $12 \mathrm{~kg} \mathrm{ha}^{-1}$ of $\mathrm{Zn}$. Except for the rate $0 \mathrm{~kg} \mathrm{ha}^{-1}$ of $\mathrm{Zn}$ (control) in the crop grown in a Typic Quartzipsamment, the foliar $\mathrm{N}, \mathrm{P}, \mathrm{K}, \mathrm{Ca}, \mathrm{Mg}, \mathrm{S}, \mathrm{B}, \mathrm{Cu}, \mathrm{Fe}, \mathrm{Mn}$, and $\mathrm{Zn}$ concentration were within or slightly above the levels considered suitable for soybean cultivation. The introduction of the gene that confers glyphosate resistance only affected plant height, number of pods per plant (NPP) and SDW yield. Except for P and Zn available, the soil chemical properties were not influenced by the treatments. There was a significant interaction of varieties $\times \mathrm{Zn}$ rates, with negative effect of the glyphosate application on the foliar $\mathrm{Ca}, \mathrm{B}, \mathrm{Fe}$, and $\mathrm{Mn}$ concentration.

\section{Funding}

The authors are thankful to the staff of soil fertility and microbiology of National Soybean Research Center for conducting the experiments and to CNPQ for granting the scholarship to the first author.

\section{References}

Abreu, M. F., and B. van Raij. 1996. Soil reaction effect on DTPA-TEA and Mehlich 1 extractable zinc. Bragantia 55:357-63. doi:10.1590/S0006-87051996000200022.

Baligar, V. C., N. K. Fageria, and Z. L. He. 2001. Nutrient use efficiency in plants. Communications Soil Science and Plant Analysis 32:921-50. doi:10.1081/CSS-100104098.

Cakmak, I., A. Yazici, Y. Tutus, and L. Ozturk. 2009. Glyphosate reduced seed and leaf concentrations of calcium, manganese, magnesium, and iron in non-glyphosate resistant soybean. European Journal of Agronomy 31:114-19. doi:10.1016/j.eja.2009.07.001.

Coupland, D. 1985. Metabolism of glyphosate in plants. In The herbicide glyphosate, ed. E. Grossarb, and D. A. Atkinson, 25-34. London, UK: Butterworths.

Davies, P. J. 1995. Plant hormones; physiology, biochemistry, and molecular biology. Dordrecht, The Netherlands: Kluwer Academic Publishers.

Delannay, X., T. W. Bauman, D. H. Beighley, M. J. Buettner, H. D. Coble, M. S. Defelice, C. W. Derting, T. J. Diedrick, J. L. Griffen, E. S. Hagood, F. G. Hancock, S. E. Hart, B. J. Lavallee, M. M. Loux, W. E. Lueschen, K. W. Matson, C. K. Moots, E. Murdock, A. D. Nickell, M. D. K. Owen, E. H. Paschall II, L. M. Prochaska, P. J. Raymond, D. B. Reynolds, D. B. Rhodes, F. W. Roeth, P. L. Sprankle, L. J. Tarochione, C. N. Tinius, R. H. Walker, L. M. Wax, H. D. Weigelt, and S. R. Padgette. 1995. Yield evaluation of a glyphosate tolerant soybean line after treatment with glyphosate. Crop Science 35:1461-67. doi:10.2135/cropsci1995.0011183X003500050033x. 
Duke, S. O., J. Lydon, W. C. Koskinen, T. B. Moorman, R. L. Chaney, and R. Hammerschmidt. 2012. Glyphosate effects on plant mineral nutrition, crop rhizosfere microbiota, and plant disease in glyphosate-resistant crops. Journal of Agricultural and Food Chemistry 60:10375-97. doi:10.1021/jf302436u.

Eker, S., J. Ozturk, A. Yazici, B. Erenoglu, V. Romheld, and I. Cakmak. 2006. Foliar-applied glyphosate substantially reduced uptake and transport of iron and manganese in sunflower (Helianthus annuus L.) plants. Journal of Agricultural and Food Chemistry 54:1019-25. doi:10.1021/jf0625196.

EMBRAPA (Empresa Brasileira de Pesquisa Agropecuária). 1997. Manual of soil analysis methods. Rio de Janeiro, Brazil: National Research Center of Soils.

Fageria, N. K. 2009. The use of nutrients in crop plants. Boca Raton, USA: CRC Press.

Fageria, N. K., A. Moreira, L. A. C. Moraes, and M. F. Moraes. 2014. Influence of lime and gypsum on yield and yield components of soybean and changes in soil chemical properties. Communications Soil Science and Plant Analysis 45:271-83. doi:10.1080/00103624.2013.861906.

Fageria, N. K., and A. B. Santos. 2011. Zinc nutrition of lowland rice. Communications Soil Science and Plant Analysis 42:1719-27. doi:10.1080/00103624.2011.584591.

Fehr, W. R., C. E. Caviness, D. T. Burmood, and J. S. Pennington. 1971. Stage of development description for soybeans (Glycine max (L.) Merrill). Crop Science 11:929-31. doi:10.2135/cropsci1971.0011183X001100060051x.

Fritschi, F. B., and J. D. Ray. 2007. Soybean leaf nitrogen, chlorophyll content, and chlorophyll a/b ratio. Photosynthetica 45:92-98. doi:10.1007/s11099-007-0014-4.

Gonçalves, J. M., E. R. B. Souza, E. P. Fernandes, W. M. Leandro, and C. J. Tavares. 2014. Nutritional efficiency of glyphosate-resistant soybean without glyphosate. Científica 42:157-63. doi:10.15361/1984-5529.2014v42n2p157163.

Graham, R. D., and M. J. Webb. 1991. Micronutrients and disease resistance and tolerance in plants. In Micronutrients in agriculture, ed. J. J. Mortwedt, F. R. Cox, L. M. Shuman, and R. M. Welch, 329-70. Madison, USA: Soil Science Society of America.

Havlin, J., J. D. Beaton, S. L. Tisdale, and W. L. Nelson. 1999. Soil fertility and fertilizers; an introduction nutrient management. Upper Saddle River, USA: Prentice Hall.

Ikeda, F. S. 2013. Weed resistance in soybeans resistant to glyphosate. Informe Agropecuário 34:1-8.

Lindsay, W. L., and W. A. Norvell. 1978. Development of a DTPA test for zinc, iron, manganese, and copper. Soil Science Society of America Journal 42:421-28. doi:10.2136/sssaj1978.03615995004200030009x.

Loneragan, J. F., D. L. Grunes, R. M. Welch, E. A. Aduayi, A. Tengah, V. A. Lazar, and E. E. Cary. 1982. Phosphorus accumulation and toxicity in leaves in relation to zinc supply. Soil Science Society of America Journal 46:345-52. doi:10.2136/sssaj1982.03615995004600020027x.

Lopez-Gorostiaga, O. E., and E. Malavolta. 1974. Studies on the zinc and phosphate relationships in plant nutrition. Anais Da Escola Superior De Agricultura Luiz De Queiroz 31:467-83.

Loué, A. 1993. Oligoéléments en Agriculture [Micronutrient in Agriculture]. Antibes, France: SCPA-NATHAN.

Malavolta, E., G. C. Vitti, and S. A. Oliveira. 1997. Evaluation of nutritional status of plants; principles and applications. Piracicaba, Brazil: Potafós.

Marschner, H. 1995. Mineral nutrition of higher plants. London, UK: Academic Press.

Mehlich, A. 1978. New extractant for soil test evaluation of phosphorus, potassium, magnesium, calcium, sodium, manganese and zinc. Communications in Soil Science and Plant Analysis 9:477-92. doi:10.1080/00103627809366824.

Moreira, A., and E. Malavolta. 2001. Sources, rates and extractants of phosphorus on alfalfa and centrosema. Pesquisa Agropecuária Brasileira 36:519-1527.

Moreira, A., L. A. C. Moraes, and N. K. Fageria. 2015. Zinc and amino-acids on the yield and nutritional state of alfalfa grown in the tropical soil. Journal of Plant Nutrition 38:780-94. doi:10.1080/01904167.2014.944710.

Oliveira, S. C., M. C. G. Costa, R.,. C. S. Chagas, T. A. B. Fenilli, R. Heinrichs, C. P. Cabral, and E. Malavolta. 2003. Response of two rice cultivar to rates of zinc applied as oxysulfate. Pesquisa Agropecuária Brasileira 38:387-96.

Ritchey, K. D., F. R. Cox, E. Z. Galrão, and R. S. Yost. 1986. Zinc availability for corn, sorghum and soybean in a clayey dark-red latosol. Pesquisa Agropecuária Brasileira 21:215-25.

Rodrigues, B. N., and F. S. Almeida. 1998. Guide of herbicides. Londrina, Brazil: Editions of authors.

Rosolem, C. A., G. J. M. Andrade, I. P. Lisboa, and S. M. Zoca. 2010. Manganese uptake and redistribution in soybean as affected by glyphosate. Revista Brasileira De Ciência Do Solo 34:1915-22. doi:10.1590/S0100-06832010000600016.

Serra, A. P., M. E. Marchetti, A. C. S. Candido, A. C. R. Dias, and P. J. Christoffoleti. 2011. Glyphosate influence on nitrogen, manganese, iron, copper and zinc nutritional efficiency in glyphosate resistant soybean. Ciência Rural 41:77-84. doi:10.1590/S0103-84782011000100013.

TPS. (Tecnologias de produção de soja). 2013. Technology of soybean yield in central region of Brazil. Londrina, Brazil: Embrapa Soybean.

Xavier, T. F., F. L. Campos, A. S. F. Araújo, and V. B. Santos. 2008. Phenotipic behavior in greenhouse of soybean cultivar in Piauí northern region. Caatinga 21:5-8.

Zobiole, L. H. S., R. J. Kremer, R. S. Oliveira Junior, and J. Constantin. 2012. Glyphosate effects on photosynthesis, nutrient accumulation, and nodulation in glyphosatesresistant soybean. Journal of Plant Nutrition and Soil Science 175:319-30. doi:10.1002/jpln.201000434. 